\title{
Anger, Anxiety and Corruption Perceptions: Evidence from France
}

\author{
Sarah Birch \\ King's College London \\ Sarah.birch@kcl.ac.uk \\ Tel: +44 2078480447 \\ Nicholas Allen \\ Royal Holloway University of London \\ Nicholas.allen@rhul.ac.uk \\ Katja Sarmiento-Mirwaldt \\ Brunel University \\ Katja.Sarmiento-Mirwaldt@brunel.ac.uk
}

\begin{abstract}
This paper assesses the roles of anxiety and anger in shaping people's perceptions of politicians' integrity. Drawing on recent work on the role of affect in shaping political judgment, the paper develops a theoretical model of the anticipated role of anger and anxiety in structuring reactions to allegations of political misconduct. The model is tested on a unique dataset that includes results of an experiment fielded as part of a survey carried out in January 2013 among a representative sample of the French adult population. The analysis finds that those in whom politically dubious actions generate anxiety are more sensitive to contextual details than other respondents, though the role of anger in modulating ethical judgments is less clear-cut, dampening attention to information about negatively-assessed behavior but enhancing attention to information about behavior that is assessed more positively.
\end{abstract}

Acknowledgements: Research for this paper has been supported by British Academy grant SG101785. We are grateful to Ray Duch and colleagues on the French Cooperative Campaign Analysis Project for their help and advice.

Keywords: emotion, corruption perceptions, French politics, public ethics 


\section{Anger, Anxiety and Corruption Perceptions: Evidence from France}

It has become a truism in the contemporary world that citizens tend to look askance at the morals of their elected leaders. Whether, as in Lord Acton's phrase, politics corrupts, or whether people are simply wont to find fault with those who govern them is unclear. Suffice it to say, the citizens of most modern states have a marked tendency to see their elected representatives as being susceptible to corruption and misconduct. Yet although we know that people tend to have a fairly jaundiced view of politics and politicians, we know far less about why some people are more inclined than others to see their leaders in a negative light. A better understanding of how people form ethical judgments may hold one of the keys to improving citizens' perceptions of elite political conduct. If political elites are made aware of the processes through which negative evaluations of them are formed, they may be able to alter their conduct and its communication to citizens so as to short-circuit such reactions. This could in turn reduce disillusionment with politics.

Over the past thirty years or so, research on attitudes toward political ethics has spawned a growing literature generally referred to under the rubric of 'corruption perceptions'. We have gained some insight into the demographic, attitudinal and behavioral correlates of perceptions of elected representatives' conduct (Allen and Birch 2012; Blais et al. 2010; Davis et al. 2004;

Johnston 1986; Redlawsk and McCann 2005) as well as the role of framing in shaping the ethical judgments people make about those who govern them (Chanley et al. 1994; Gonzalez et al. 1995). Yet a very large proportion of the variation in corruption perceptions remains unexplained in existing studies, which suggests that there are factors at play that have not yet been identified by scholars working in this field. We suggest that one such factor is affect, and that drawing on 
insights from the political psychology of emotions will enable us better to explain how ethical evaluations of politicians are formed.

The importance of emotions in shaping people's attitudes to politics has played an integral part in the philosophy of moral reasoning since at least the time of David Hume. More recently, the role of affect in political evaluations has received considerable attention from social and political psychologists (e.g. Arceneaux 2012; Brader, Valentino and Suhay 2008; Ladd and Lenz 2008; 2011; Marcus 2002; 2003; Marcus, Neuman and MacKuen 2000; 2011; MacKuen et al. 2007; MacKuen et al. 2010; Masters 2001; Masters and Sullivan 1989; Nadeau, Niemi and Amato 1995; Redlawsk 2006; Sears, 2001). Yet this attention has yet to penetrate corruption perceptions research to any great degree: this field has to date been largely inductive and has generally lacked a strong grounding in psychological theories of judgment. This paper seeks to go some way toward remedying this lacuna by probing the role of affect in structuring perceptions of political leaders' integrity.

Our starting point is Norris's $(1999 ; 2011)$ idea that 'critical citizens' who are disenchanted with the actions of their leaders can be functional for democracy in providing feedback and input into the political process. Following MacKuen et al. (2010), we argue that, due to the confounding effects of emotions, not all those who are disaffected with politicians exhibit the same cognitive orientations that the 'critical citizens' thesis predicts. We suggest that affective reactions to politicians condition the extent to which negative evaluations of political behavior make people more critical of politicians. We argue that these cognitive processes condition corruption perceptions, and that the role of affect in shaping corruption perceptions fills an important gap in our understanding of why some people are more likely than others to perceive politicians as corrupt. 
We posit that affect matters for the way people assimilate and process information about political situations. Specifically, anxiety can be expected to make people pay closer attention to information about specific instances of corruption and make more nuanced judgments, while anger leads them to rely more on stereotypes and is likely to be associated instead with blanket condemnations of political actors. We test this supposition on data collected as part of a January 2013 sample survey of the population in France. Most previous research on 'affect effects' has been carried out on US data, but the United States is in many ways an unusual democracy: parties are weak and regionally fragmented, and personal vote cultivation is common. France is arguably more typical of established democracies; it is a party-based unitary system with a hybrid executive type and parliamentary government. Like many other democracies, France has witnessed a marked decline in trust in politicians in recent decades (Norris 2011: 70-9), and trust in political elites is a topic of frequent debate in the French media. The survey was designed specifically to measure emotional predispositions toward politicians; it also included a specially designed experiment crafted to assess the role of different emotions in shaping evaluations of elite behavior.

The paper proceeds as follows: the next section outlines the political psychology literature on the role of affect in political judgment and sets out our hypotheses, while the third section sketches relevant details of the French political context. The paper then reports our empirical results, including the results of a survey experiment designed to probe how people respond to the context of morally dubious acts. A final section discusses the findings and concludes. 


\section{Affect and Ethics: The Roles of Anger and Anxiety}

Representative democracy is a political regime type that relies on people making judgments about who should govern them. One component of such evaluation is ethical judgment which pertains to the honesty of politicians and the propriety of their conduct (Peters and Welch 1980; McCurley and Mondak 1995; Newman 2003). Just as recent advances in political psychology have provided us with insight into the role of emotions in political judgment, so they can help us to understand better how citizens go about evaluating the probity of their leaders.

Psychologists have long been aware that people engage in two broad forms of reasoning, one based on 'high information' and paying close attention to the task at hand, and the other on 'low information' or peripheral processing (e.g. Chaiken 1980; Devine, Sedikides and Fuhrman 1989; Kuklinski and Quirk 2000; Lieberman, Schneider and Oschner 2003; Kahneman 2011; Lodge and Taber 2000; 2013; Petty and Cacioppo 1986; Sears 2001). More recently, George Marcus, Russell Neuman and Michael MacKuen have built on this understanding of political cognition to develop Affective Intelligence Theory, which posits that the mode of reasoning employed by individuals is conditioned by affective responses to political events. Specifically, people normally pay limited attention to politics and use 'low information' techniques when processing political information, but when political events make them anxious, their 'surveillance system' is activated and they switch to high-information reasoning (Marcus 2002; Marcus, Neuman and MacKuen 2000; Marcus, MacKuen and Neuman 2011; MacKuen et al. 2007; MacKuen et al. 2010; cf Brader 2011). The role of emotion as an antecedent to moral judgment has also been confirmed in neurological studies (Decety and Cacioppo 2012; Green et al. 2001; Greene and Haidt 2002; Haidt 2001; 2012). 
Anxiety is not the only emotion that conditions how people react to politics. Numerous studies have found that anger and anxiety generate different reactions (e.g. Barenbaum, Fujita and Pfennig 1995; Conover and Feldman 1986; Lerner and Keltner 2000; 2001; Lerner et al. 2003; Lerner and Tiedens 2006; Marcus 2002; Redlawsk, Civettini and Lau 2007; Tiedens and Linton 2001). To summarize the relevant findings from this body of research, anxiety is generated by the fear of a threat over which one believes one has little control. It is associated with perceived uncertainty and more in-depth processing of information. Anger, by contrast, results from goal frustration. It is associated with perceptions of greater certainty and personal efficacy, as well as a lower propensity to engage in reflection. Thus if anxiety makes people pay closer attention to political information and to think more carefully, anger tends to have the opposite effect: it causes people to engage in low-information processing that relies on the use of habit and heuristics (Bodenhausen, Sheppard and Kramer 1994; Huddy, Feldman and Cassese 2007; MacKuen et al. 2010; Marcus 2002), to be indiscriminately critical (Goldberg, Lerner and Tetlock 1999; Lerner, Goldberg and Tetlock 1998), and to attribute negative outcomes to individuals rather than to circumstances (Keltner, Ellsworth and Edwards 1993; Lerner, Goldberg and Tetlock 1998).

Most previous political science research on the role played by emotion in political judgment has been carried out in the context of policy positions and political support. There has been very limited analysis of the impact of different emotional reactions on reasoning about the integrity of political processes. ${ }^{1}$ Casual observation does, however, suggest that the actions of politicians often evoke strong reactions in people. If the popular media are anything to go by,

\footnotetext{
${ }^{1}$ An exception is an interesting paper by Steenbergen and Ellis 2006, which has aims that differ somewhat from those of the current analysis.
} 
dubious political shenanigans elicit a combination of outrage, revulsion and alarm. Such affective orientations can be expected to be the cumulative effect of reactions to media reports consumed over an extended period. What interests us here is how these reactions in the minds of citizens influence ethical evaluations, both alone and in combination.

Our first hypothesis is that those with 'negative' affect toward political leaders (anxiety or anger) should evaluate their ethical behavior more negatively. It is not possible to say whether in this context affect 'causes' evaluations or evaluations 'cause' affect, but we can expect to find an association between the two.

Our second and more substantive hypothesis draws on the above-cited literature to predict the impact of affect on individuals' responsiveness to information. Bearing in mind that people generally hear about politics in concrete contexts, we can hypothesize that the emotions evoked by politicians in general will condition how much attention people pay to the circumstances surrounding specific instances of political behavior. Specifically, greater attention will be paid to information about such circumstances by individuals who respond to political leaders with feelings of anxiety, and such individuals will be more responsive to variations in contextual information, whereas individuals who respond to politicians with a feeling of anger will be more likely to ignore the subtleties of the circumstances and engage in blanket condemnation of the political class as a whole. In other words, anxiety should be expected to evoke in people the cognitive pre-requisites to 'critical citizenship': analytic acuity and the propensity to link information about concrete situations to abstract norms. Anger, on the contrary, ought to blunt people's critical faculties, hamper their propensity to undertake demanding evaluations of new information, and increase the likelihood that they will attribute negative outcomes to individuals rather than to contextual factors. Thus anger ought to lead to 
more generalized condemnation of politicians as corrupt. The theoretical implications of this outcome will be discussed in the conclusion.

\section{The French context}

Representative politics in France has two principal foci: parties, which are the core institutions among the political elite; and individual politicians, whose characteristics are highly salient for the French electorate (Converse and Pierce 1986: 280-2). Both parties and individual politicians have been implicated in networks of corruption in France in recent years.

The French self-image has long been that of a 'Latin' state in which many forms of ethical misdemeanor in politics are accorded a fairly high degree of tolerance (Lascoumes 2010; 2011; Mény 1992; Pujas and Rhodes 1999). Expressions such as 'petits arrangements avec la probité' (Lascoumes 2010; 2011), 'l'arrangement à la française' (Pujas and Rhodes 1999: 43), 'corruption à la française' (Mény 1992: 14), and 'tout est pourri' (Ruggiero 1996: 129) are used in France to characterize this historic state of affairs. ${ }^{2}$ French regulatory practice in this domain bears this view out to a great extent. There appears to have been widespread disregard for the letter of the law in the sphere of campaign finance, and successive amnesties have been granted to politicians caught engaging in malpractice (Mény 1996; Ruggiero 1996). Likewise, survey data suggest both relatively high levels of tolerance for deviations from personal moral codes among the French citizenry (Lascoumes 2010; 2011) and an attitude toward corruption in high

\footnotetext{
2 These phrases respectively and loosely translate as: 'Little arrangements with probity' understood ironically in terms of adjusting rules to suit one's needs; 'The French arrangement'; 'French corruption'; and 'Everything is rotten'.
} 
places that is somewhat relaxed when it comes to conflicts of interest (Lascoumes 2010; 2011; Mény 1992; 1996).

Just over 20 years ago, Mény (1992: 20) went so far as to claim that: "French culture, unlike Anglo-American culture, is ignorant of 'conflict of interest', in other words, a situation where an individual, by virtue of his/her accumulated but contradictory 'loyalties', is obliged to sacrifice one of the interests that s/he ought to defend". ${ }^{3}$ He went on to explain that the acquisition of political and personal interests was seen in France as a convenient means of making policy more efficiently, in spite of the likely resulting breaches of impartiality (Mény 1992: 20). And though he admitted that there were in fact numerous safeguards in France against conflict of interest, he maintained that the concept was one foreign to Gallic sensibilities (Mény 1992: 31-2).

From the public's perspective, concern about corruption in France has been a topic that has moved over the popular consciousness in waves. French politics experienced a dramatic rise in popular awareness of corrupt practices in the 1980s, following a combination of increased entrepreneurialism by investigating judges who sought support from the media (and the public) for their inquires, and the rise of investigative journalism (Adut 2004; Chalaby 2004; Fay 1995; Karpik 2000; Pujas and Rhodes 1999; Ruggiero 1996). This period, labeled the 'ethical transition' by Pujas and Rhodes (1999: 56), was one in which “greater political competition, the role $[\ldots]$ of the media and the intervention for prosecuting magistrates $[\ldots]$ produced revelations of corruption, defined them as 'scandalous', secured prosecution and helped generate public

\footnotetext{
3 “'La culture française, à la difference de la culture anglo-américaine, ignore le 'conflit d'intérêt', c'est-à-dire une situation où l'individu, en raison de 'loyautés' cumulées mais contradictories, doit sacrifier l'un des intérêts qu'il devrait défendre." (authors' translation)
} 
support for reform." Greater public awareness of malfeasance in politics since the 1980s has been credited with a variety of effects, including increased levels of political disaffection and the rise of the far-right Front National (Shields 2006: 123-7). ${ }^{4}$

Specific areas of concern in France are breaches of campaign finance regulations (Mény 1992; 1996; Pujas and Rhodes 1999; Ruggiero 1996), clientelism (Lascoumes 2010; Mény 1992; Ruggiero 1996; Shields 2006) and the misappropriation of public resources (Fay 1995; Karpik 2000; Mény 1992; Shields 2006). In the latter context, a French particularity is the practice known as the 'cumul des mandats' or accumulation of elected posts. The practice enables politicians to build a local support base, which can be useful at the time of national elections, but which also lends itself to clientelism and pork-barrel politics (Lascoumes 2011: 13-14; Mény 1992: 51-95; 1996: 169-70; Ruggiero 1996: 117; Shields 2006: 133). For instance, mayoralities have long been a favorite additional post for many national-level politicians due to the power French mayors wield at the local level. In 2014, the year following our field research, the ability of politicians to accumulate mandates in this way was restricted due to concerns about clientelism (Vie Publique, 2015).

A team led by Lascoumes $(2010 ; 2011)$ has conducted perhaps the most extensive research to date on French corruption perceptions, based on a survey carried out in 2006. The results of this project confirm that the French public has a fairly cynical view of their leaders: approximately three in five survey respondents expressed the view that most leaders were corrupt. At the same time, many French people exhibit relatively high degrees of tolerance for many activities that are commonly labeled 'grey' corruption (Heidenheimer 1970), including

\footnotetext{
${ }^{4}$ For a different view, see Mény 1992: 14. Moreover, as Williams notes, the far right has long been at the forefront of crusades against corruption in France (Williams 1970: 50).
} 
favoritism, clientelism and the extraction of small amounts of personal benefit (e.g. hospitality) from public office. Indeed, the ethically 'tolerant' constituted 59.3 percent of Lascoumes's (2010: 101-5) sample, though outright bribery and extortion were viewed very negatively. The authors identified a 'tension' among the French public between their tendency to condemn corruption in the abstract and their propensity to tolerate in practice many concrete acts that were generally acknowledged to be normatively unacceptable (Lascoumes 2010: 141; cf Lascoumes 2011). ${ }^{5}$

Over the past few years, France has experienced yet another wave of concern about political corruption following a series of scandals involving bribery and the misappropriation of public resources. A poll conducted in 2011 by TNS-Sofres found that corruption perceptions were at the highest level recorded since polling on this question was initiated in 1977, with 72 percent of French respondents saying that most political leaders were corrupt. ${ }^{6}$ Political corruption was a major issue in the 2012 presidential election, and in July of that year, newlyelected president François Hollande established an official commission, headed by former prime minister Lionel Jospin, to investigate various aspects of political morality, including campaign finance and the 'cumul des mandats'. The data employed in this paper was thus collected at a time (January 2013) when political corruption was a central topic of debate in France. It is likely that emotional reactions toward political malfeasance among our respondents will be conditioned

${ }^{5}$ Tensions such as these have been noted in a variety of democratic contexts; e.g. Prothro and Grigg 1960; Allen and Birch 2015.

${ }^{6}$ Le Post 28 September 2011, http://archiveslepost.huffingtonpost.fr/article/2011/09/28/2600582_les-politiques-plutot-corrompus-pour-troisfrancais-sur-quatre.html. 
both by our survey instruments and by memories of recent scandals, which will prime

respondents to react in certain ways. From the point of view of our research design, this tendency can be seen as beneficial, as it provides grounds for our supposition that a hypothetical situation might in theory trigger instantaneous evaluations, even in the absence of detailed reflection on the specifics of the circumstance in question.

\section{Empirical evidence}

Data to assess the predictions set out above were drawn from a representative online survey of the adult French population administered between 15 and 25 January 2013 as part of the French Co-operative Campaign Analysis Project (FCCAP) (see the online Appendix for methodological details). The survey included a module designed to assess corruption perceptions among the French population, and to analyze the impact of affect on those perceptions. A general question on the perceived honesty and integrity of political actors confirms previous findings that the French are generally mistrustful of their politicians (see Table 1).

-- Table 1 about here -

Following approaches to the measurement of affect developed in the US context (Marcus 2003; Marcus et al. 2006), respondents were also asked to identify emotions that accorded with their feelings toward elected politicians. Respondents were presented with a list of eight common emotions — four positive and four negative — and invited to select as many as they liked. ${ }^{7}$

The eight emotions and the frequencies for each response are listed in Table 2. The first thing that stands out from the figures in this table is that negative emotions massively outweigh positive feelings. The number of respondents listing the least-common negative emotion (unease)

\footnotetext{
${ }^{7}$ The original wording is set out in the online Appendix.
} 
was twice that naming the most common positive response (hope). Of the negative emotions, the most commonly named was fear, followed closely by disgust — over half the sample maintained that politicians made them feel either afraid or disgusted, which is testimony to the generally low regard in which the French public holds its elected representatives. Feelings of anger and unease were expressed by just under a quarter of the sample-24.6 percent and 23.8 percent respectively. Further analysis indicates that 60.0 percent of the respondents listed fear and/or unease, while 56.4 percent named disgust and/or anger. A total of 37.4 percent of respondents listed fear or unease AND disgust or anger, which accords with Steenbergen and Ellis's observation that anger and anxiety frequently coexist in citizens' reactions to their political leaders (Steenbergen and Ellis 2006: 111).

-- Table 2 about here --

Of the positive emotions, hope was the most common, being named by 11.7 percent, followed by confidence at 9.3 percent. Happiness and pride trailed the list at 3.5 percent and 2.7 percent respectively, while 12.7 percent of the sample claimed to feel none of the emotions listed when contemplating their political leaders.

Focusing on those five emotions expressed by at least ten percent of the sample-fear, disgust, anger, unease and hope — it is possible to calculate the mean honesty evaluation for each feeling (see Table 3). The results confirm our expectations: those expressing negative emotions were significantly more likely to rate politicians' honesty as poor than those with more positive feelings. And as hypothesized, those who were angry and/or disgusted were more critical of politicians than the afraid and the uneasy. This is evident from both the mean evaluations from those reporting each emotion, and the combined angry/disgusted versus afraid/uneasy means, as reported at the bottom of the table. We cannot of course be sure of the direction of causality 
between these two variables, but this is not our principal concern in this analysis. Suffice it to say, emotional reactions are clearly linked to ethical evaluations and they are linked in ways that conform to expectations. Another noteworthy aspect of the data in this table is the similarity between the scores for 'angry' and 'disgusted' on the one hand and 'afraid' and 'uneasy' on the other (cf Conover and Feldman 1986). This suggests that these emotions are in fact tapping two underlying dimensions, a supposition borne out by confirmatory factor analysis (see table AIII in the online Appendix). In view of this, two variables were created for subsequent analysis, one designating anger and/or disgust (henceforth referred to as 'anger and revulsion', or 'anger' for short) and the other designating fear and/or unease (referred to subsequently as 'anxiety').

-- Table 3 about here -

Based on this analysis, we can be confident that when it comes to ethical evaluations of politicians, there is a clear association between affect and judgment, with negative emotions being associated with more critical views. It also appears that, as in previous studies, the four negative emotions considered here fall into two categories - those associated with fear and those linked with anger. The main question to be addressed in this paper revolves around the respective roles of anxiety and anger in conditioning how people process information about politicians' behavior when forming ethical judgments. In order to investigate this question and test our central hypothesis that the anxious will be more responsive to contextual information while the angry will be more likely to make blanket condemnations of politicians, we embedded a factorial vignette experiment in the survey that was designed to present respondents with an example of morally questionable political activity and which enabled us to manipulate the information to 
which people were exposed. ${ }^{8}$ The experiment was positioned after and at some distance from the question about emotional reactions to political leaders. It is to the results of this experiment that we now turn.

\section{Experimental design}

In our experimental vignette, respondents were presented with a hypothetical scenario adapted from an earlier French study (Lascoumes 2010: 128). The information in it was then systematically manipulated in ways that we expected to condition ethical evaluations. The $2 \times 2 \times 2$ set of combinations generated a total of eight distinct versions of the vignette. We also presented a control group with a base-line version of the scenario stripped of most of the information. There were thus nine different versions of the vignette (a full list is set out in Table AII in the online Appendix), which operationalized different versions of information designed to tap aspects of political ethics known to be salient in contemporary France: (1) whether the politician engaged in the 'cumul des mandats'; (2) the potential of the action in question to benefit the local constituency and thus provide indirect political benefit for the politician (pork-barrel politics); and (3) the potential of the action to provide direct financial benefit for the politician. Based on the above discussion, all three behaviors are widely disapproved of by French political elites, and all three are behaviors about which there is commonly-voiced elite concern in France. The three behaviors are thus both salient and negatively valenced in elite discourse. Our interest here is to determine whether elite norms are reflected in popular attitudes, and whether affect conditions the applications of those norms to specific circumstances.

\footnotetext{
${ }^{8}$ Vignette-based experiments have been widely used in the analysis of social judgments, for which they were originally developed by sociologists (Rossi and Anderson 1982).
} 
The vignette involves a situation that Pierre Lascoumes and colleagues describe as one of 'grey' corruption: a fictitious French Senator elected from a tourist region who helps ensure that a law is passed to facilitate the construction of hotels at the seaside. ${ }^{9}$ The number of mandates is varied by telling respondents either that "The Senator is also the mayor of the capital of the region" or "The Senator holds no other political offices other than his seat in the Senate". Benefit to the constituency (which can be expected to translate into political benefit) is varied by telling respondents either that "The company that builds the hotels employs local people from that region" or that "The company that builds the hotels employs people from another region to carry out the building work." Finally, financial benefit is varied by adding either that "The company is owned by several people including the Senator's wife" or that "The company is owned by people with no personal connections to the Senator." The choice of an instance of 'grey' corruption is designed to ensure that there are aspects of the Senator's action that require cognitive attention; the behavior is meant to be morally ambiguous and resistant to immediate judgment.

Though the vignette is fictitious and is intentionally vague enough not to reflect the circumstances of any particular corruption scandal, there had been several scandals with similar circumstances at the time the survey was fielded. A number of these involved construction projects where politicians had been involved in making key decisions that had then been questioned on grounds of self-interest (e.g. Berretta 2014; Gross 2011; Le Monde 2007). There had also been several scandals where politicians had been accused of using their power as

\footnotetext{
${ }^{9}$ In the Lascoumes study, 31 percent of the sample found this highly problematic (très grave) (Lascoumes 2010: 128; cf Lascoumes 2011: 33). The same study also finds that senators, who are indirectly elected in France, are generally viewed by the public as being slightly less corrupt than deputies in the National Assembly (Lascoumes 2010: 15).
} 
mayors and other local-level representatives to serve their national-level political interests, and vice versa (e.g. Groult, 2013; Nicolas, 2013; Pilgrim, 2013).

In order to test our hypotheses about the conditioning effects of anger and anxiety on judgments of political conduct, respondents were asked to evaluate the action described in the vignette by means of the following question: "Please indicate your opinion about the Senator's actions using this 0 to 10 scale," followed by a scale where 0 was coded as "Totally acceptable" and 10 as "Totally unacceptable." 10

\section{Results}

The final column of Table 4 presents average scores in response to the 'acceptability' question, broken down by treatment. These findings indicate that, as expected, members of the French public are generally antipathetic toward politicians. None of the variants of the vignette presented to our respondents evoked mean responses lower than the midpoint of 5.5 on the $0-10$ 'unacceptability' scale employed for this purpose, which suggests that even in the most favorable circumstances, the actions of politicians are viewed with suspicion by most French people. ${ }^{11}$ Nevertheless, the results of this experiment also demonstrate that French citizens do respond to situational cues, and they respond in ways that are largely consonant with expectations.

-- Table 4 about here --

The one partial exception to this general result is that people appear in practice relatively relaxed about the 'cumul des mandats'. The accumulation of political posts at different levels of

\footnotetext{
${ }^{10}$ The original question wording is set out in the online Appendix.

${ }^{11}$ Birch and Allen (2011) report similar findings in the British context.
} 
government seemed not to bother respondents, despite the importance accorded to it by French political commentators and the recently-established commission tasked with investigating political morality.

When it comes to constituency benefit, people responded positively to a measure that might bring jobs to the area represented by the Senator. They did not seem to view this measure as illegitimate pandering to local interests for partisan benefit, or if they did recognize the porkbarrel elements of this action, they nevertheless judged it positively, presumably because they viewed a boost to local employment as a boon that outweighed considerations of the Senator's possible ulterior motives. This finding suggests that the citizenry as a whole has a view of pork that differs somewhat from that of their political elite. Combined with responses to the 'cumul des mandats' manipulation, it also suggests that many French citizens are somewhat more relaxed about certain practices that might perturb an Anglo-Saxon soul.

The strongest results by far were shaped by information about self-interest and possible personal financial gain for the fictitious Senator. By far the highest 'unacceptability' score was given to those versions of the vignette in which the public-works project in question would benefit the Senator's wife, and the lowest score was achieved by those versions in which there was no suggestion of personal benefit. The French thus appear to respond most strongly to actions that reflect the classic definition of political corruption as abuse of public office for private gain. In this respect, French ethical orientations seem no different from those in the United States.

-- Table 5 about here -

The results of the bivariate analysis are confirmed by multivariate (OLS) results, presented in Table 5. This additional analysis shows that, even when controlling for the other 
manipulations and their interactions (which is conventional in the analysis of factorial vignettes of this type), the fact that a politician's action promises to benefit his constituency leads people to see that action as less unacceptable-i.e. more acceptable - than if there is no benefit. Contrariwise, a suggestion of personal financial gain for the politician evokes strong negative reactions among respondents, as expected. As in the bivariate analysis, the fact of the politician holding two mandates rather than one appears to have no discernible impact on popular evaluations of his actions.

To test our core hypothesis, we segment the sample by emotional reaction, focusing on those in whom politicians elicit feelings of anger/disgust and anxiety. The results are presented in Table 6. The headline findings are that respondents' evaluations of the behavior of politicians display systematic patterns, and that these patterns are conditioned by negative affective attitudes toward politicians. In the three models based on samples of those in whom politicians evoke feelings of anxiety and/or anger, the coefficients for the three manipulations are virtually all larger than they are in the model based on those who exhibited neither anger nor anxiety (though the coefficients designating dual mandate remain insignificant in all four cases).

-- Table 6 about here --

Most importantly of all from the perspective of the main hypothesis of this paper, those in whom politicians evoke anxiety pay greater attention to the details of the vignette, as predicted by Affective Intelligence Theory. When it comes to anger, the results partially confirm expectations. As anticipated, the coefficient corresponding to the self-interest treatment is considerably smaller than that in the anxious and non-anxious-non-angry models, suggesting that those in whom politicians elicit anger are generally less sensitive to the contextual nuances of corruption. This comports with the idea that anger induces people to generalize across categories 
of individuals and dampens their ability to make nuanced evaluations based on contextual details.

The behavior of the constituency-benefit coefficient is somewhat puzzling, however. In both the models based on the angry and the anxious subsets, this coefficient is larger than it is in the model based on the non-anxious-non-angry sample. Given that this aspect of the vignette was generally welcomed by respondents, despite the whiff of pork-barrel politics that the wording was designed to convey, it seems that the negative emotions of both anger and anxiety can condition people to respond positively to certain aspects of politicians' behavior. It is unclear if this finding is due to the specific features of the particular vignette, but it suggests that anger and anxiety may have different effects when conditioning the interpretation of 'positive' and 'negative' information. This effect is also evident in the model of those expressing both anger/revulsion and anxiety (the 4th column of Table 6). The relevant coefficient designating the self-interest vignette variant is of a magnitude between that in the model of the 'angry' alone and that in the model of the 'anxious' alone, whereas the coefficient for the constituency-benefit variable is larger than that in the other two models.

In sum, the self-interest component of the vignette performed exactly as predicted by our application of Affective Intelligence Theory to corruption perceptions: an anxious orientation toward politicians magnified negative evaluations of a political actor described as engaging in self-interested behavior, while anger toward politicians dampened such evaluations. Given that putting one's own interest ahead of the citizenry's in general is in many senses the most straightforward type of unethical political behavior, this aspect of the experiment lends strong support to our hypothesis. The ambiguous findings from the other two components of the vignette suggest that there may be discrepancies between mass and elite evaluations of political 
ethics, as has been found in the UK context (Allen and Birch 2012). Though there has been much elite condemnation of dual mandates in France, this does not appear to be a practice that especially bothers French citizens. None of the coefficients for the dual mandate component of the vignette was significant. As far as the constituency benefit component is concerned, the attitude of French citizens appears to be the opposite of that of elites; whereas French elites tend to condemn blatant pork-barrel politics as a form of clientelism, French citizens, like their American counterparts, positively welcome politicians who 'bring home the bacon'. These unexpected findings are an intriguing aspect of our analysis that suggests there is scope for further specifying the precise contours of popular expectations of politicians in France.

\section{Conclusion}

The manipulation of emotional reactions for political benefit has long been the stock-in-trade of those who seek to make a career in politics. It ought not to surprise, therefore, that accounts of wrong-doing by political actors - fictitious or otherwise — should provoke negative reactions in survey respondents. Yet it is unlikely that even the most astute political rhetorician has gained the insight into how emotion affects information processing about political acts to the extent of recent studies in political psychology.

This paper has gone some way toward advancing our understanding in this field by extending research on anxiety and anger to the domain of corruption perceptions, thus breaking new ground in the study of popular attitudes toward political elites. The paper's findings confirm that certain emotions are strongly associated with moral evaluations of political leaders, specifically that anxiety generates greater attentiveness to contextual detail than does anger. Certainly our results support the core contention of Affective Intelligence Theory that anxiety 
prompts greater attention to information and improves cognitive processing. This is an important result, as it suggests a new way of thinking about how corruption perceptions are shaped. Given that 60 percent of the French sample employed here reported that politicians make them feel anxious, it can be conjectured that in most people emotional reactions to politics heighten their ability to make sense of the details of situations, and that it is a minority who engage in blanket condemnations of political behavior (cf Steenbergen and Ellis 2006). From a normative perspective this is perhaps encouraging, as it lends support to the 'critical citizen' thesis.

The results with regard to the effects of anger are more ambiguous. Like Redlawsk, Civettini and Lau (2007) in their analysis of the influence of affect on voting decisions, we find that anger exhibits somewhat inconsistent effects, significantly dampening attention to contextual information when it comes to negatively-assessed behavior but not when it comes to positively-assessed behavior. This makes sense if it is the negatively-assessed behavior that generates anger, but the data limitations of the survey on which this analysis is based do not enable us to explore this causal link.

It must also be borne in mind that this study has been carried out in a particular cultural context, and while the underlying role of emotions in conditioning attitudes toward political elites is unlikely to vary considerably across cultures, there may well be cross-cultural variations in the extent to which politics evokes emotions of different types, and thus the prominence of the effects identified here. It is also quite possible that in different cultural contexts the same elite behavior evokes different emotions in citizens; Persson, Rothstein and Teorell (2013) note that in highly-corrupt contexts citizens often have a positive value orientation toward many forms of corruption, which could be expected fundamentally to change the ways in which emotions affect evaluations of behavior. 
Clearly, much still remains to be done to unravel the relative role of cognitive and affective processing in shaping judgments of politicians. For example, further research could usefully examine the broader context in which 'affect effects' are most likely to play an important role in molding ethical judgments. The recent rise of left- and right-wing populism in countries as diverse as the US, Austria, Greece, Spain and the UK in the wake of economic stress and rising financial insecurity suggests that emotional reactions to personal economic distress might condition popular reactions toward and against mainstream politics and acceptance of populist political alternatives whose words and deeds are widely condemned by large sectors of the media (Belluci 2014; Hackner, Rehm and Schelsigner 2013; Rehm 2011; Tillman 2016; Wroe 2016). ${ }^{12}$

Another profitable line of research would be to assess what types of political events and experiences are most likely to make people angry or anxious about corruption, and whether those who are more attentive to public affairs are more likely to report these emotional reactions. Research in a different vein might usefully explore the systemic implications of cognitive and affective processing, especially in relation to the cognitive circumstances under which people are most adept at playing the role of 'critical citizens'; possible non-linearities in the role of affect on information processing might also yield interesting insights. As an obvious next step, future research could also usefully examine how both popular normative standards and affective reactions to political ethics condition political mobilization and behavior.

In sum, the research presented here has shown that affect matters for corruption perceptions. Though scholars have for decades been studying the factors association with

\footnotetext{
${ }^{12} \mathrm{We}$ are grateful to an anonymous reviewer for hinting at such a potential extension of this research.
} 
popular evaluation of legislative ethics, there has been virtually no previous consideration of the role of affective responses in conditioning evaluations of elite political behavior. We have demonstrated that this is an unfortunate oversights, and in so doing we hope to have opened up a promising new area of research. 


\section{References}

Adut, A. (2004). Scandal as norm entrepreneurship strategy: Corruption and the French investigating magistrates. Theory and Society, 33(5), 529-578.

Allen, N. and S. Birch. (2011). Political Conduct and Misconduct: Probing Public Opinion. Parliamentary Affairs, 64(1), 61-81.

--- (2012). On Either Side of a Moat? Elite and Mass Attitudes towards Right and Wrong. European Journal of Political Research, 51(1), 89-116.

--- (2015). Ethics and integrity in British Politics: How Citizens Judge Their Politicians' Conduct and Why it Matters. Cambridge: Cambridge University Press.

Arceneaux, K. (2012). Cognitive Biases and the Strength of Political Arguments. American Journal of Political Science, 56(2), 271-285.

Barenbaum, H., F. Fujita and J. Pfennig. (1995). Consistency, Specificity, and Correlates of Negative Emotions. Journal of Personality and Social Psychology, 68(2), 342-352.

Bellucci, P. (2014). The Political Consequences of Blame Attribution for the Economic Crisis in the 2013 Italian National Election. Journal of Elections, Public Opinion and Parties 24(2), 243-263.

Berretta, E. (2014). “Hippodrome de Compiègne - Éric Woerth: 'J'ai été trâ̂né dans la boue' L'ancien ministre du Budget détaille les forces politiques qui ont gonflé l'affaire de l'hippodrome de Compiègne en passe de s'écrouler..." Le Point, 25 October. Available at http://www.lepoint.fr/politique/emmanuel-berretta/hippodrome-de-compiegne-ericwoerth-j-ai-ete-traine-dans-la-boue-25-10-2014-1875588_1897.php. Accessed 28 August 2016. 
Birch, S. and N. Allen. (2015). Judging Politicians: The Role of Political Sophistication in Shaping How People Evaluate the Ethical Behavior of their Political Leaders. European Journal of Political Research, 54(1), 43-60.

Blais, A., E. Gidengil, P. Fournier, N. Nevitte, J. Everett, and J. Kim. (2010). Political Judgments, Perceptions of Facts and Partisan Effects. Electoral Studies, 29(2), 1-12.

Bodenahausen, G. V., L. A. Sheppard and G. P. Kramer. (1994). Negative Affect and Social Judgment: The Differential Impact of Anger and Sadness. European Journal of Social Psychology, 24(1), 45-62.

Brader, T. (2011). The Political Relevance of Emotions; 'Reassessing' Revisited. Political Psychology, 32(2), 337-346.

Brader, T., N. A. Valentino and E. Suhay. (2008). What Triggers Public Opposition to Immigration? Anxiety, Group Cues, and Immigration Threat. American Journal of Political Science, 52(4), 959-978.

Chaiken, S. (1980). Heuristic versus Systematic Information Processing and the Use of Source versus Message Cues in Persuasion. Journal of Personality and Social Psychology, 39(5), $752-766$.

Chalaby, J. K. (2004), Scandal and the Rise of Investigative Reporting in France. American Behavioral Scientist, 47(9), 1194-1207.

Chanley, V., J. L. Sullivan, M. H. Gonzalez and M. Bull Kovera. (1994). Lust and Avarice in Politics: Damage Control by Four Politicians Accused of Wrongdoing (or Politics as Usual). American Politics Research, 22(3), 297-333.

Conover, P. and S. Feldman. (1986) Emotional Reactions to the Economy: I'm Mad as Hell and I'm not Going to Take it Anymore. American Journal of Political Science, 30(1), 50-78. 
Converse, P. E. and R. Pierce. (1986). Political Representation in France. Cambridge, MA: Harvard University Press.

Davis, C. L., R. A. Camp and K. M. Coleman. (2004). The Influence of Party Systems on Citizens' Perceptions of Corruption and Electoral Response in Latin America. Comparative Political Studies, 37(6), 677-703.

Decety, J. and S. Cacioppo. (2012). The Speed of Morality: A High-Density Electrical Neuroimaging Study. Journal of Neurophysiology, 108(11), 3068-3072.

Devine, P. G, C. Sedikides and R. W. Fuhrman. (1989). Goals in Social Information Processing: The Case of Anticipated Interaction. Journal of Personality and Social Psychology, 56(5), $680-90$.

Fay, C. (1995). Political Sleaze in France: Forms and Issues. Parliamentary Affairs 48(4), 663676.

Gibson, J. L. (2008). Challenges to the Impartiality of State Supreme Courts: Legitimacy Theory and "New-Style" Judicial Campaigns. American Political Science Review, 102(1), 59-75.

Goldberg, J. H., J. S. Lerner and P. E. Tetlock. (1999). Rage and Reason: The Psychology of the Intuitive Prosecutor. European Journal of Social Psychology, 29(5-6), 781-795.

Gonzalez, M. H., M. Bull Kovera, J. L. Sullivan and V. Chanley. (1995). Private Reactions to Public Transgressions: Predictors of Evaluative Responses to Allegations of Political Misconduct. Personality and Social Psychology Bulletin, 21(2), 136-147.

Greene, J, and J. Haidt. (2002). How (and Where) Does Moral Judgment Work? Trends in Cognitive Sciences, 6(12), 517-523.

Greene, J., R. B. Sommerville, L. E. Nystrom, J. M. Darley and J. D. Cohen. (2001). An fMRI Investigation of Emotional Engagement in Moral Judgment. Science, 293, 2105-2108. 
Gross, E. (2011). "L'affaire Guérini pour les nuls." Le Nouvel observateur, 8 September. Available at http://tempsreel.nouvelobs.com/politique/20110908.OBS0012/l-affaireguerini-pour-les-nuls.html. Accessed 28 August 2016.

Groult, C.-H. (2013). “Cumul des mandats : trois sénateurs sur quatre sont concernés.” Le Figaro, 19 September. Available at http://www.lefigaro.fr/politique/2013/09/19/0100220130919ARTFIG00492-cumul-des-mandats-trois-senateurs-sur-quatre-sontconcernes.php. Accessed 28 August 2016.

Hacker, J. S., P. Rehm and M. Schlesinger. (2013). The Insecure American: Economic Experiences, Financial Worries and Policy Attitudes. Perspectives on Politics 11(1), 2349.

Haidt, J. (2001). The Emotional Dog and its Rational Tail: A Social Intuitionist Approach to Moral Judgment. Psychological Review, 108(4), 814-834.

--- (2012). The Righteous Mind: Why Good People Are Divided by Politics and Religion. London: Penguin.

Heidenheimer, A.J. (1970). The Context of Analysis: Introduction. In A.J. Heidenheimer (ed.), Political Corruption: Readings in Comparative Analysis. New York: Holt, Rinehart and Winston, Inc, 3-28.

Huddy, L., S. Feldman and E. Cassese. (2007). On the Distinct Political Effects of Anxiety and Anger. In R. Neuman, G. E. Marcus, A. N. Crigler and M. MacKuen (eds.), Affective Intelligence: Dynamics of Emotion in Political Thinking and Behavior, Chicago and London: University of Chicago Press, 202-230.

Johnston, M. (1986). Right and Wrong in American Politics: Popular Conceptions of Corruption. Polity, 18(3), 367-91. 
Kahneman, D. (2011). Thinking, Fast and Slow, London: Penguin.

Karpik, L. (2000). “L'avancée de la justice menace-t-elle la République?” Le Débat, 2000/3, 238-257.

Keltner, D., P. C. Ellsworth and K. Edwards. (1993). Beyond Simple Pessimism: Effects of Sadness and Anger on Social Perception. Journal of Personality and Social Psychology, 64(5), 740-752.

Kuklinski, J. H., and P. J. Quirk. (2000). Reconsidering the Rational Public: Cognition, Heuristics, and Mass Opinion. In A. Lupia, M. D. McCubbins, and S. L. Popkin (eds.), Elements of Reason: Cognition, Choice, and the Bounds of Rationality, Cambridge: Cambridge University Press, 153-182.

Lacsoumes, P. (ed.). (2010). Favoritisme et corruption à la française: petits arrangements avec la probité, Paris: Presses Sciences Po.

--- (2011). Une démocratie corruptible: Arrangements, favoritisme et conflits d'intérêts, Paris:

Seuil.

Lerner, J.S., J.H. Goldberg and P.E. Tetlock. (1998). Sober Second Thought: The Effects of Accountability, Anger and Authoritarianism on Attributions of Responsibility. Personality and Social Psychology Bulletin, 24(6), 563-574.

Lerner, J. S., R. M. Gonzalez, D. A. Small, and B. Fischhoff. (2003). Effects of Fear and Anger on Perceived Risks of Terrorism: A National Field Experiment. Psychological Science, 14(2), 144-151.

Lerner, J. S. and L. Z. Tiedens. (2006). Portrait of The Angry Decision Maker: How Appraisal Tendencies Shape Anger's Influence on Cognition. Journal of Behavioral Decision Making, 19(2), 115-137. 
Lieberman, M. D., D. Schneider and K. N. Oschner. (2003). Is Political Cognition like Riding a Bicycle? How Cognitive Neuroscience Can Inform Research on Political Thinking. Political Psychology, 24(4), 681-704.

Lodge, M. and C. Taber. (2000). Three Steps Toward a Theory of Motivated Political Reasoning. In A. Lupia, M. D. McCubbins and S. L. Popkin (eds.), Elements of Reason: Cognition, Choice, and the Bounds of Rationality, Cambridge: Cambridge University Press, 183-213. --- (2013). The Rationalizing Voter, Cambridge: Cambridge University Press.

McCurley, C., and J. J. Mondak. (1995). Inspected by \#1184063113: The Influence of Incumbents' Competence and Integrity in U.S. House Elections. American Journal of Political Science, 39(4), 864-885.

MacKuen, M., J. Wolak, L. Keele and G. E. Marcus. (2010). Civic Engagements: Resolute Partisanship or Reflective Deliberation. American Journal of Political Science, 54(2), 440-58.

Marcus, G. E. (2002), The Sentimental Citizen: Emotion in Democratic Politics, University Park, PA: Pennsylvania State University Press.

--- (2003). The Psychology of Emotion and Politics. In D. O. Sears, L. Huddy and R Jervis (eds.), Oxford Handbook of Political Psychology. Oxford: Oxford University Press, 182-221.

Marcus, G. E., M. MacKuen, J. Wolak and L. Keele. (2006). The Measure and Mismeasure of Emotion. In David P. Redlawsk (ed.), Feeling Politics: Emotion in Political Information Processing, Basingstoke: Palgrave-Macmillan, 31-45.

Marcus, G. E., W. R. Neuman and M. MacKuen. (2000). Affective Intelligence and Political Judgment. Chicago: University of Chicago Press. 
Marcus, G. E., M. MacKuen and W. R. Neuman. (2011). Parsimony and Complexity:

Developing and Testing Theories of Affective Intelligence. Political Psychology, 32(2), 323336.

Masters, R. D. (2001). Cognitive Neuroscience, Emotion and Leadership. In J. H. Kuklinski (ed.), Citizens and Politics: Perspectives from Political Psychology. Cambirdge: Cambridge University Press, 68-102.

Masters, R. D. and D. G. Sullivan. (1989). Nonverbal Displays and Political Leadership in France and the United States. Political Behavior, 11(2): 123-156.

Mény, Y. (1992). La Corruption de la République, Paris: Fayard.

--- (1996). Corruption French Style. In W. Little and E. Posada-Carbó (eds.), Political Corruption in Europe and Latin America. London: Macmillan, 159-172.

Le Monde. 2007. "Feu l'affaire des HLM de Paris.” 21 November. Available at http://www.lemonde.fr/societe/article/2006/03/14/feu-1-affaire-des-hlm-deparis_750542_3224.html. Accessed 28 August 2016.

Nadeau, R., R. G. Niemi and T. Amato. (1995). Emotions, Issue Importance and Political Learning. American Journal of Political Science, 39(3), 558-74.

Neuman, R., G. E. Marcus, A. N. Crigler and M. MacKuen. (eds.) (2007). Affective Intelligence: Dynamics of Emotion in Political Thinking and Behavior. Chicago and London: University of Chicago Press.

Neuman, R., G. E. Marcus, M. MacKuen and L. Keele. (2007). The Third Way; The Theory of Affective Intelligence and American Democracy. In Neuman, R., G. E. Marcus, A. N. Crigler and M. MacKuen (eds.), Affective Intelligence: Dynamics of Emotion in Political Thinking and Behavior. Chicago and London: University of Chicago Press, 124-51. 
Newman, B. (2003). Integrity and Presidential Approval, 1980-2000. Public Opinion Quarterly, 67(3), 335-367.

Nicolas, A. (2013). "Cinq affaires judiciaires qui touchent Serge Dassault de plus ou moins loin.” France $T V$ info, 16 September. Available at http://www.francetvinfo.fr/politique/affaire/cinq-affaires-judiciaires-qui-touchent-sergedassault-de-plus-ou-moins-loin_412725.html. Accessed 28 August 2016.

Norris, P. (ed.) (1999). Critical Citizens: Global Support for Democratic Government, Oxford: Oxford University Press.

--- (2011). Democratic Deficit: Critical Citizens Revisited, Cambridge: Cambridge University Press.

Persson, A., B. Rothstein and J. Teorell. (2013). Why Anticorruption Reforms Fail—Systemic Corruption as a Collective Action Problem. Governance 26(3), 449-471.

Peters, J. G. and Welch, S. (1980). The Effects of Charges of Corruption on Voting Behavior in Congressional Elections. American Political Science Review, 74(3), 697-708.

Petty, R. and J. T. Cacioppo. (1986). Communication and Persuasion: Central and Peripheral Routes to Attitude Change. New York; Springer.

Pilgrim, S. (2013). “Socialist's vote-buying reveals Marseille corruption.” France24, 23 May. Available at http://www.france24.com/en/20130523-vote-buying-socialist-mpcorruption-marseille-sylvie-andrieux-france. Accessed 28 August 2016.

Prothro, J. W. and C. M. Grigg. (1960). Fundamental Principles of Democracy: Bases of Agreement and Disagreement. Journal of Politics, 22(2), 276-94.

Pujas, V. and M. Rhodes. (1999). Party finance and political scandal in Italy, Spain and France. West European Politics, 22(3), 41-63. 
Redlawsk, D. P. (ed.) (2006). Feeling Politics: Emotion in Political Information Processing, Basingstoke: Palgrave-Macmillan.

Redlawsk, D. P., A. J. W. Civetti and R. R. Lau. (2007). Affective Intelligence and Voting: Information Processing and Learning in a Campaign. In Neuman, R., G. E. Marcus, A. N. Crigler and M. MacKuen (eds.), Affective Intelligence: Dynamics of Emotion in Political Thinking and Behavior. Chicago and London: University of Chicago Press, 152-79.

Redlawsk, D. P., and J. A. McCann. (2005). Popular Interpretations of Corruption and Their Partisan Consequences. Political Behavior, 27(3), 261-84.

Rehm, P. (2011). Risk Inequality and the Polarized American Electorate. British Journal of Political Science, 41(2), 363-87.

Rossi, P. H. and A. B. Anderson. (1982). The Factorial Survey Approach: An Introduction. In: P. Rossi and S. Nock (eds.), Measuring Social Judgments: The Factorial Survey Approach. Beverley Hills: Sage, 15-67.

Ruggiero, V. (1996). France: Corruption as Resentment. Journal of Law and Society, 23(1), 113131.

Sears, D. O. (2001). The Role of Affect in Symbolic Politics. In J. H. Kuklinski (ed.), Citizens and Politics: Perspectives from Political Psychology, Cambridge: Cambridge University Press, 14-40.

Shields, J.G. (2006). Political Representation in France: A Crisis of Democracy? Parliamentary Affairs, 59(1), 118-137.

Sniderman, P. M., and D. B. Grob. (1996). Innovations in Experimental Design in General Population Attitude Surveys. Annual Review of Sociology, 22, 377-399. 
Steenbergen, M. R. and C. Ellis. (2006). Fear and Loathing in American Elections: Context, Traits and Negative Candidate Affect. In D. P. Redlawsk (ed.), Feeling Politics: Emotion in Political Information Processing. Basingstoke: Palgrave Macmillan, 109-133.

Tiedens, L. Z. and S. Linton. (2001). Judgment Under Emotional Certainty and Uncertainty: The Effects of Specific Emotions on Information Processing. Journal of Personality and Social Psychology, 81(6), 973-988.

Tillman, E. R. (2016). Has the Global Financial Crisis Changed Citizen Behaviour? A FourCountry Study. In J. Vowles and G. Xezonakis (eds.), Globalization and Domestic Politics. Oxford: Oxford University Press, 113-.130.

Vie Publique. (2015). “Cumul des madats: Une pratique restreinte à compter de 2017.” http://www.vie-publique.fr/actualite/dossier/cumul-mandats-2017/cumul-mandatspratique-restreinte-compter-2017.html. Accessed 28 August 2016.

Williams, P. M. (1970). Wars, Plots and Scandals in Post-War France. Cambridge: Cambridge University Press.

Wroe, A. (2016). "Economic Insecurity and Political Trust in the United States." American Politics Research, 44(1), 131-163. 


\section{Tables}

TABLE 1: "Overall, how would you rate the standards of honesty and integrity of elected politicians in France today?"

\begin{tabular}{lc}
\hline & $\%$ \\
\hline Very high & 2.3 \\
Somewhat high & 9.9 \\
Neither high nor low & 24.7 \\
Somewhat low & 28.9 \\
Very low & 29.6 \\
Don't know & 4.6 \\
\hline \hline
\end{tabular}


TABLE 2: "Which, if any, of the following words describe your feelings about elected politicians?"

\begin{tabular}{lc}
\hline \hline Emotion & Frequency \\
\hline Angry & $24.6 \%(\mathrm{~N}=264)$ \\
Disgusted & $52.4 \%(\mathrm{~N}=562)$ \\
Uneasy & $23.8 \%(\mathrm{~N}=255)$ \\
Afraid & $56.0 \%(\mathrm{~N}=601)$ \\
Happy & $3.5 \%(\mathrm{~N}=38)$ \\
Hopeful & $11.7 \%(\mathrm{~N}=126)$ \\
Confident & $9.3 \%(\mathrm{~N}=100)$ \\
Proud & $2.7 \%(\mathrm{~N}=29)$ \\
None of these & $12.7 \%(\mathrm{~N}=136)$ \\
\hline \hline
\end{tabular}

Notes: For the purposes of display, the eight emotions have been grouped into positive and negative categories; see above for the exact question wording. The emotions named sum to more than $100 \%$ as respondents were able to provide more than one response to this item. 
TABLE 3: Mean response to "Overall, how would you rate the standards of honesty and integrity of elected politicians in France today?" by emotion evoked

\begin{tabular}{lccc}
\hline \hline & $\begin{array}{c}\text { Mean } \\
\text { honesty } \\
\text { evaluation }\end{array}$ & $\begin{array}{c}\text { Standard } \\
\text { deviation }\end{array}$ & $\mathrm{N}$ \\
\hline Angry & $1.82^{* * *}$ & 1.05 & 261 \\
Disgusted & $1.85^{* * *}$ & 0.95 & 556 \\
Uneasy & $2.09 *$ & 1.01 & 253 \\
Afraid & $2.05 * * *$ & 0.95 & 597 \\
Hopeful & $2.93 * * *$ & 1.05 & 124 \\
Angry and/or disgusted ('angry') & $1.88^{* * *}$ & 0.97 & 598 \\
Uneasy and/or afraid ('anxious') & $2.09 * * *$ & 0.97 & 639 \\
\hline \hline
\end{tabular}

Notes: This table includes only those emotions that were named by more than 10 percent of respondents. Responses to the honesty question are coded so that a higher score corresponds to perception of greater honesty. Significance levels indicate whether the mean for respondents listing the emotion in question was statistically different from that for those respondents not listing this emotion; $*=\mathrm{p}<0.05 ; * *=\mathrm{p}<0.01 ; * * *=\mathrm{p}<0.001$. 
TABLE 4 Vignette design and effects of manipulations on reaction to vignette (Question: How acceptable/unacceptable?)

\begin{tabular}{|c|c|c|}
\hline & English text & $\begin{array}{l}\text { Mean score (standard } \\
\text { error) }\end{array}$ \\
\hline & $\begin{array}{l}\text { A senator elected from a tourist } \\
\text { region gets adopted a law } \\
\text { facilitating the construction of } \\
\text { hotels at the seaside }\end{array}$ & \\
\hline \multicolumn{3}{|l|}{ M1: Dual mandate } \\
\hline Yes & $\begin{array}{l}\text { V1a The senator is also the mayor } \\
\text { of the capital of the region. }\end{array}$ & $\begin{array}{c}6.65(2.55) \\
\mathrm{N}=397\end{array}$ \\
\hline \multirow[t]{2}{*}{ No } & $\begin{array}{l}\text { V1b The senator holds no other } \\
\text { political offices other than his seat } \\
\text { in the senate. }\end{array}$ & $\begin{array}{l}6.41(2.68) \\
\mathrm{N}=450\end{array}$ \\
\hline & & Difference: 0.24 \\
\hline \multicolumn{3}{|c|}{ M2: Constituency benefit (potential political gain) } \\
\hline $\begin{array}{l}\text { Exclusive benefit to } \\
\text { the representative's } \\
\text { constituency }\end{array}$ & $\begin{array}{l}\text { V2a The company that builds the } \\
\text { hotels employs local people from } \\
\text { that region }\end{array}$ & $\begin{array}{l}6.20(2.78) \\
\mathrm{N}=379\end{array}$ \\
\hline \multirow[t]{2}{*}{$\begin{array}{l}\text { Non-exclusive benefit } \\
\text { to the representative's } \\
\text { constituency }\end{array}$} & $\begin{array}{l}\text { V2b The company that builds the } \\
\text { hotels employs people from } \\
\text { another region to carry out the } \\
\text { building work. }\end{array}$ & $\begin{array}{l}6.79(2.46) \\
\mathrm{N}=468\end{array}$ \\
\hline & & Difference: $-0.59 * * *$ \\
\hline \multicolumn{3}{|c|}{ M3: Self-interest (potential financial gain) } \\
\hline $\begin{array}{l}\text { Self-interested } \\
\text { behavior }\end{array}$ & $\begin{array}{l}\text { V3a The company is owned by } \\
\text { several people including the } \\
\text { senator's wife. }\end{array}$ & $\begin{array}{c}7.34(2.38) \\
\mathrm{N}=389\end{array}$ \\
\hline \multirow[t]{2}{*}{$\begin{array}{l}\text { Non self interested } \\
\text { behavior }\end{array}$} & $\begin{array}{l}\mathrm{V} 3 \mathrm{~b} \text { The company is owned by } \\
\text { people with no personal } \\
\text { connections to the senator. }\end{array}$ & $\begin{array}{c}5.84(2.62) \\
\mathrm{N}=458\end{array}$ \\
\hline & & Difference: $1.50 * * *$ \\
\hline Baseline vignette/control & & $\begin{array}{c}6.73(2.86) \\
\mathrm{N}=115 \\
\end{array}$ \\
\hline
\end{tabular}

Notes: The final column provides mean responses for treatment groups. Lower scores indicate respondents found the behavior more acceptable; higher scores indicate respondents found the behavior less acceptable. Significance levels: $*=p<0.05 ; * *=p<0.01$; $* * *=p<0.001$. 
TABLE 5: Variation in judgments of acceptability/unacceptability: OLS regressions

\begin{tabular}{|c|c|}
\hline Variable & Coefficients (standard errors) \\
\hline Dual mandate & $.116 \quad(.283)$ \\
\hline Constituency benefit & $-1.031 * * *(.289)$ \\
\hline Self-interest & $1.263 * * *(.278)$ \\
\hline Dual mandate $*$ constituency benefit & $.104 \quad(.350)$ \\
\hline Dual mandate $*$ self-interest & $(.349)$ \\
\hline Constituency benefit $*$ self-interest & $(.350)$ \\
\hline Constant & 6.185 \\
\hline $\mathrm{N}$ & 846 \\
\hline Adj. $\mathrm{R}^{2}$ & .098 \\
\hline
\end{tabular}

Note: $*=\mathrm{p}<0.05 ; * *=\mathrm{p}<0.01 ; * * *=\mathrm{p}<0.001 ;$ standard errors are in parentheses. 
TABLE 6: Variation in judgments of acceptability/unacceptability: OLS regressions $x$ affective reactions toward politicians

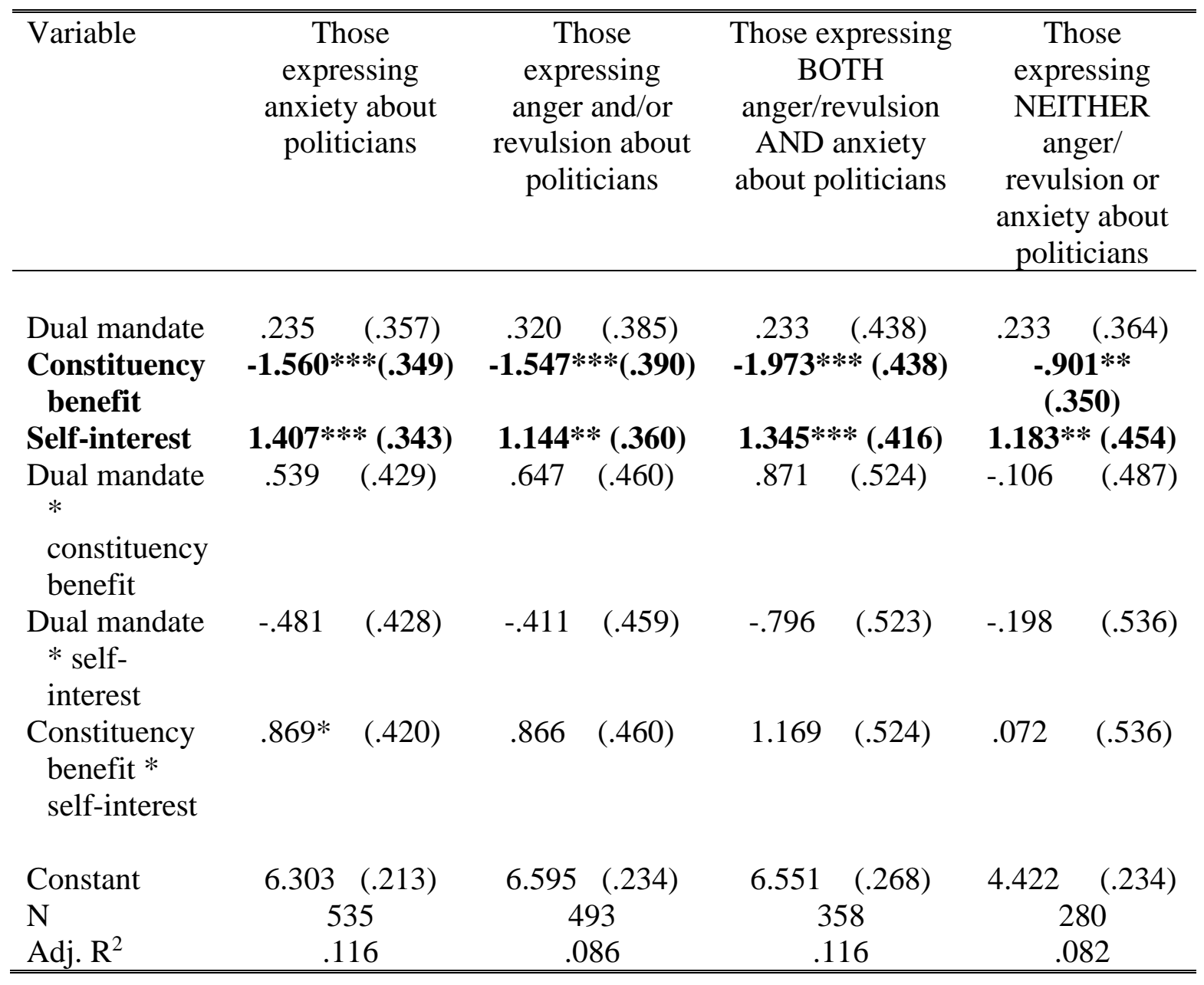

Notes: Cell entries are coefficients (standard errors); $*=\mathrm{p}<0.05 ; * *=\mathrm{p}<0.01 ; * * *=\mathrm{p}<0.001$; standard errors are in parentheses 